\title{
MODULATION OF GROWTH, GASEOUS EXCHANGE PARAMETERS AND ANTIOXIDANTS IN WHEAT (TRITICUM AESTIVUM L.) BY FOLIAR SPRAY OF GLYCINEBETAINE (GB) AT DIFFERENT GROWTH STAGES UNDER SALT $\left(\mathrm{NA}_{2} \mathrm{SO}_{4}\right)$ STRESS
}

\author{
TALAT, A. - NAWAZ, K. - HUSSAIN, K. - FATIMA, S. - AKHTAR, S. - SIDDIQI, E. H. - \\ JHAN, S. - BASHIR, S. - JAVERIA, M. \\ Department of Botany, University of Gujrat, Gujrat, Pakistan \\ *Corresponding author \\ e-mail:khalid.nawaz@uog.edu.pk \\ (Received $13^{\text {th }}$ Jan 2017; accepted $20^{\text {th }}$ Mar 2017)
}

\begin{abstract}
This experiment was conducted to evaluate the impact of foliar application of glycinebetaine on vegetative and reproductive growth stages of two wheat (Triticum aestivum L.) varieties under $\mathrm{Na}_{2} \mathrm{SO}_{4}$ stress $(150 \mathrm{mM})$. There were three levels $(0 \mathrm{mM}, 50 \mathrm{mM}$ and $100 \mathrm{mM})$ of glycinebetaine $(\mathrm{GB})$ applied as foliar spray. Data regarding biomass, growth parameters, gaseous exchange and antioxidant activities were recorded. Salt stress reduced the growth attributes, Net $\mathrm{CO}_{2}$ assimilation rate and antioxidant activities. However, foliar spray of GB reduced the toxic effects of salinity. GB improved the photosynthetic rate of $\mathrm{Na}_{2} \mathrm{SO}_{4}$-treated plants of both varieties; it also increased the activities of antioxidant enzymes, such as CAT and POD under saline environment. Both levels of GB i.e. $50 \mathrm{~m} M$ and $100 \mathrm{~m} M$ were almost equally effective in affecting the POD activity in salt treated plants. Finally it can be concluded that salinity tolerance can be induced by foliar application of GB.
\end{abstract}

Keywords: exogenous application, photosynthetic pigments, ROS, salinity, vegetative stage, reproductive stage

\section{Introduction}

The most limiting factors of crop productivity and quality in many geographical areas around the world are salinity (Greenway and Munns, 1980). For worldwide plant production one of the most important abiotic stress and restrictive factor is salt stress observed all over the world which causes severe crop productivity losses by affecting nutrient uptake to maintain proper metabolic activities (Debez et al., 2006; Koyro, 2006; Zafar et al., 2015). Salt stress has multiple harmful effects on plant growth and development such as decrease in water potential, ionic imbalance and in severe cases may lead to toxicity. Salt stress also affected the many other physiological processes to different degree such as; respiration, photosynthesis and uptake of ions (Meiri et al., 1971; Ramoliya et al., 2004). In addition to stunted plant growth salinity inhibit both nitrogen assimilation and protein synthesis (Cusido et al., 1987). Strong facts are present that salt affect the enzymes that involve in photosynthesis. Reduced photosynthesis under saline environment is not only due to a decline of intercellular $\mathrm{CO}_{2}$ concentration due to closing of stomata but also due to non stomatal factors (Stepien and Klobus, 2006).

One of the most important biochemical changes occur in plants due to biotic and abiotic stress is the manufacture of reactive oxygen species (ROS) by Bray et al. (2002). In salt-stressed plant the generation of ROS is commonly observed (Azevedo-Neto et al., 2006). According to Asada (1999) the mitochondria and chloroplast are important 
generators of ROS. In the absence of any defensive mechanisms ROS can critically interrupt the normal metabolism through oxidative damage in macro biomolecules. According the study of Rout and Shaw (2001) ROS can be removed by antioxidant system consisting of antioxidant enzymes such as superoxide dismutase (SOD) possessed by plants.

Glycinebetaine is useful in protecting the plants against various abiotic stresses such as salinity, water stress and temperature stress (Ashraf and Harris, 2004; Ashraf and Foolad, 2007). Betaine interacts with both water loving and phobic domains of macromolecules due to its molecular features. Betaine protect the plant against the damaging effects of excessive salt, cold, heat and freezing by maintaining the integrity of membranes and by stabilizing the structure and activity of enzymes (Gorham et al., 1985). Foliar use of GB is one of the shotgun approaches to increase stress tolerance in various crops (Ashraf and Foolad, 2007), for example salinity and drought tolerance in rice (Harinasut et al., 1996), maize (Agboma et al., 1997; Nawaz and Ashraf, 2010; Nawaz et al., 2010), tomato (Makela et al., 1998; Heuer, 2003), and wheat (Raza et al., 2006, 2007). Ashraf and Foolad, 2007 reported that effectiveness exogenous application of GB depends on different factors such as type of species, growth stage at which applied, concentration, and number of applications. Thus, the objective of the this study was to determine the effectiveness foliar applications of GB at different growth stages in inducing salt stress tolerance in two varieties of wheat.

\section{Materials and Methods}

This experiment was conducted in Botanical Garden University of Gujrat, GujratPakistan. Seeds of two wheat varieties i.e. Seher $\left(V_{1}\right)$ and Vatak $\left(V_{2}\right)$ were obtained from department of Botany University of Gujrat. River sand was used as a growth medium. Salinity $\left(\mathrm{Na}_{2} \mathrm{SO}_{4}\right)$ treatment $\left(150 \mathrm{mM} \mathrm{m}^{-1}\right)$ was applied at the time of sowing. Three levels $(0 \mathrm{mM}, 50 \mathrm{mM}$ and $100 \mathrm{mM})$ of GB were applied as foliar spray to 28 days old plants and 77 days old plants. Tween-20 (1\%) solution was used for maximum absorption of GB. Hoagland's nutrient solution was used every week thorough out the experiment. Completely randomized design (CRD) with four factors was used in this experiment. There were four replicates for each treatment. Two plants (90 days old plants) from each pot were uprooted and washed with distilled water. Data for following attributes were recorded.

\section{Growth parameters}

Shoot and root length was measured with the help of meter rod. Fresh biomass was measured with the help of electric balance. Plant samples were placed in oven at $65^{\circ} \mathrm{C}$. After 4 days shoot and root dry weight was measured with analytical balance.

\section{Gaseous exchange parameters}

Portable infrared gas analyzer (IRGA) LCA-4 ADC was used for the measurements of net $\mathrm{CO}_{2}$ assimilation rate $(A)$, transpiration rate $(E)$, stomatal conductance $(g s)$, and substomatal $\mathrm{CO}_{2}$ concentration $(\mathrm{Ci})$ were made on the 3rd leaf from top of each plant. With certain specification dimensions were completed from 10 to 2.00 p.m. These adjustments are as follow: temperature of leaf chamber (Tch) assorted from 36.2 to $42.9^{\circ} \mathrm{C}$, leaf surface area $11.35 \mathrm{~cm}^{2}$, ambient $\mathrm{CO}_{2}$ concentration (Cref) $342.12 \mu \mathrm{mol} \mathrm{mol}{ }^{-1}$, PAR (Q leaf) at leaf 
surface was maximum up to $1030 \mu \mathrm{mol} \mathrm{m}-2 \mathrm{~s}^{-1}$, leaf chamber volume gas flow rate (v) 396 $\mathrm{ml} \mathrm{min}{ }^{-1}$, ambient pressure (P) $99.95 \mathrm{kPa}$, molar flow of air /unit leaf area (Us) $221.06 \mathrm{~mol}$ $\mathrm{m}^{-2} \mathrm{~s}^{-1}$, leaf chamber molar gas flow rate (U) $251 \mu \mathrm{mol} \mathrm{s} \mathrm{s}^{-1}$.

\section{Chlorophyll contents}

A procedure described by Arnon (1949) was used to determine the chlorophyll a and $\mathrm{b}$ contents and Carotenoids.

The fresh leaves were cut into small pieces with scissor s and extracted with $80 \%$ acetone. The extract was placed at $-10{ }^{\circ} \mathrm{C}$ for overnight. The extract was centrifuged at $14000 \times \mathrm{g}$ for $5 \mathrm{mins}$ and the absorbance of the extract was measured at $645663 \mathrm{~nm}$ and 480nm using a spectrophotometer (IRMECO U2020).

\section{Electrolyte leakage}

Fresh leaves were cut into discs $\left(0.5 \mathrm{~cm}^{2}\right.$ each) and these discs were rinsed with distilled water and subsequently floated on $10 \mathrm{~mL}$ of distilled water. The electrolyte leakage of the solution was measured after $22 \mathrm{hrs}$ of floating by electrical conductivity meter. Complete measurement was taken after by putting the material in an oven at 90 ${ }^{\circ} \mathrm{C}$ for $2 \mathrm{hrs}$. Results were expressed as percentage of total conductivity.

\section{Activities of antioxidant enzymes}

Chance and Maehly (1955) procedure was followed to determine the activities of CAT and POD.

\section{Statistical analysis}

Completely randomized design (CRD) with four factors was used in this experiment. Mean \pm S.E. values were used to draw Bar graphs using the Microsoft excel software.

\section{Results}

\section{Growth attributes}

Salt stress $\left(\mathrm{Na}_{2} \mathrm{SO}_{4}\right)$ had significant harmful effects on growth (root length, shoot length) and fresh and dry biomass of two wheat varieties i.e Seher (V1) and Vatak (V2). Both varieties differed significantly for these growth attributes under saline environment (Figs. la-lf). Foliar application of GB enhanced the root length in salt treated and non-treated plants. However, $100 \mathrm{mM}$ were more effective than $50 \mathrm{mM}$. The application of $\mathrm{GB}$ at vegetative stage showed more increase in root length (Fig. 1 a). In case of shoot length, the exogenous application of GB showed random results for V1 and V2 under saline conditions. In Seher $100 \mathrm{mM}$ was more effective than $50 \mathrm{mM}$ at vegetative stage, whereas V1 showed better performance on application of $50 \mathrm{mM}$ at reproductive stage under salt stress (Fig. 1b). Analysis of Variance of data showed in Table 1 showed that $\mathrm{Na}_{2} \mathrm{SO}_{4}$ highly significantly reduced fresh and dry biomass in both varieties of wheat. Foliar application $(100 \mathrm{mM})$ was more effective than $50 \mathrm{mM}$ in both V1 and V2 applied at both stages under saline conditions. Root dry weight was improved by foliarlly applied GB. The GB level $(100 \mathrm{mM})$ showed better results than $50 \mathrm{mM}$ for V1 when applied at both growth stages under saline conditions. V2 showed better response to $50 \mathrm{mM}$ applied at vegetative stage and $100 \mathrm{mM}$ at reproductive stage under stress conditions (Fig. 1e). The effect of foliar 
spray of GB was non significant on shoot dry weight, however $100 \mathrm{mM}$ was more effective than $50 \mathrm{~mm}$ at both stages under adverse environment.
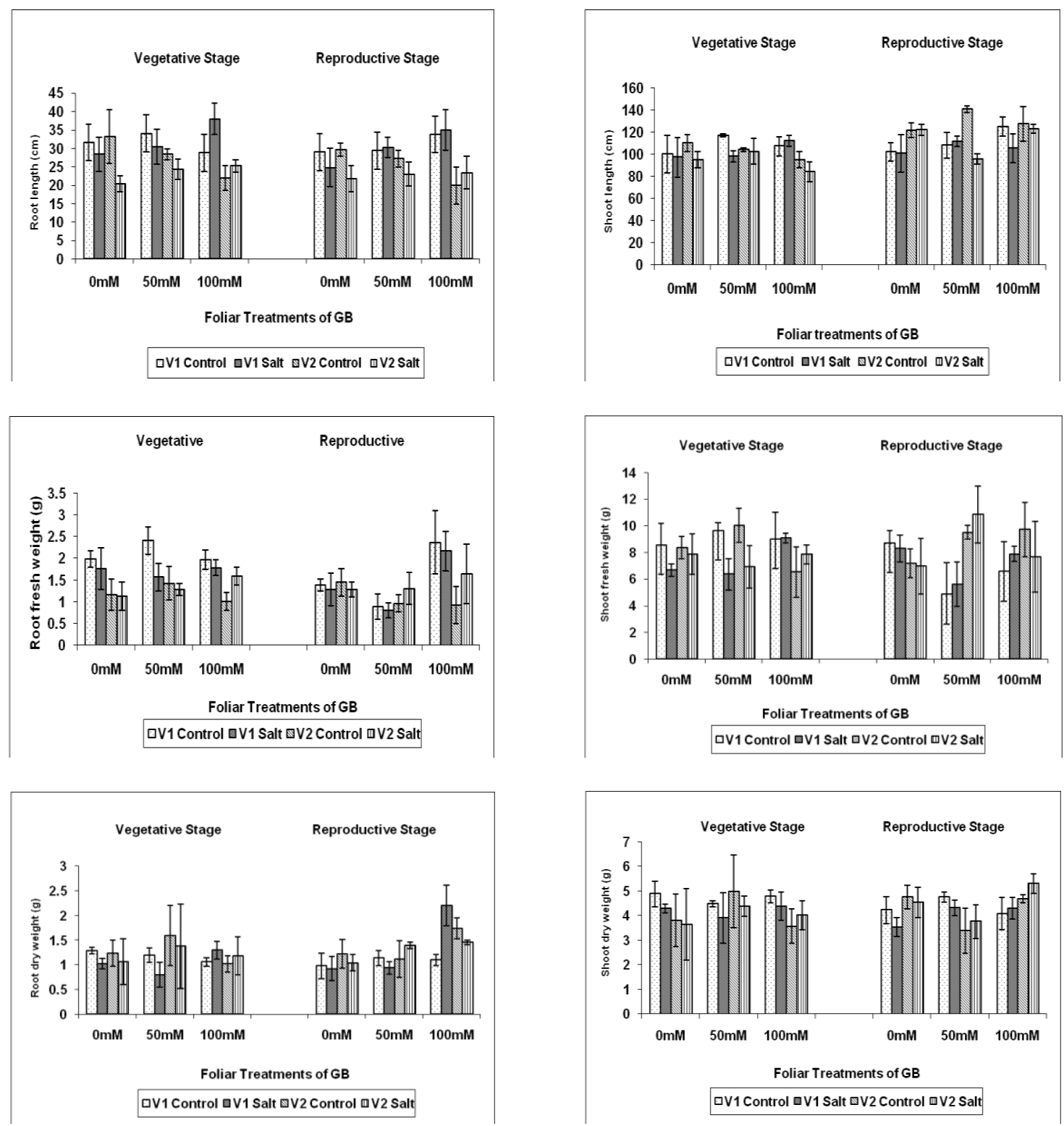

Figure 1. Impact of foliar spray of GB on root length $(a)$, shoot length (b), root fresh weight $(c)$, shoot fresh weight (d), root dry weight (e), shoot dry weight (f) of two wheat (Triticum aestivum L.) varieties under $\mathrm{Na}_{2} \mathrm{SO}_{4}$ stress

Table 1. Mean squares from ANOVA of data for growth attributes of wheat (Triticum aestivum $L$.) two varieties when different levels of $G B$ were used as foliar spray under $\mathrm{Na}_{2} \mathrm{SO}_{4}$ at the vegetative and reproductive stages

\begin{tabular}{|l|c|c|c|c|c|c|c|}
\hline SOV & d.f & $\begin{array}{c}\text { Root } \\
\text { Length }\end{array}$ & Shoot Length & $\begin{array}{c}\text { Root Fresh } \\
\text { Weight }\end{array}$ & $\begin{array}{c}\text { Root dry } \\
\text { weight }\end{array}$ & $\begin{array}{c}\text { Shoot Fresh } \\
\text { Weight }\end{array}$ & $\begin{array}{c}\text { Shoot dry } \\
\text { weight }\end{array}$ \\
\hline Salt & 1 & $2.47 * *$ & $1.28 * *$ & $98.5 * * *$ & $1.25 * * *$ & $10865.4 * * *$ & $1574.3 * * *$ \\
\hline Var & 1 & $1.24 * * *$ & $1.78 * * *$ & $3.8 * * *$ & $24.6 * * *$ & $294.4 * * *$ & $1247.9 * * *$ \\
\hline Var x Salt & 1 & $1.76 * * *$ & $2.16 * * * *$ & $3.4 * * *$ & $1.24 * *$ & $29.5 \mathrm{~ns}$ & $249.4 * * *$ \\
\hline Gr x Stages & 1 & $1.47 *$ & $2.59 * *$ & $0.053 \mathrm{~ns}$ & $1.04 * *$ & $255.8 * * *$ & $29.9 * * *$ \\
\hline
\end{tabular}




\begin{tabular}{|l|c|c|c|c|c|c|c|}
\hline Var x Gr Stages & 1 & $2.68 \mathrm{~ns}$ & $2.54^{*}$ & $1.9^{* * *}$ & $1.00^{* * *}$ & $75.7^{* *}$ & $1.4 \mathrm{~ns}$ \\
\hline Salt x Gr Stages & 1 & $3.14^{* * *}$ & $3.25^{* *}$ & $1.5^{* * *}$ & $0.09 \mathrm{~ns}$ & $65.9^{* *}$ & $0.05 \mathrm{~ns}$ \\
\hline $\begin{array}{l}\text { Salt x Var x Gr } \\
\text { Stages }\end{array}$ & 1 & $1.21^{* * *}$ & $3.8^{* * *}$ & $0.4^{* *}$ & $0.005 \mathrm{~ns}$ & $75.1^{* *}$ & $2.7 \mathrm{~ns}$ \\
\hline GB & 2 & $2.97 \mathrm{~ns}$ & $1.29 \mathrm{~ns}$ & $1.9^{* * *}$ & $0.10^{* * *}$ & $46.7^{*}$ & $41.7^{* * *}$ \\
\hline Salt x GB & 2 & $3.45^{* *}$ & $1.92 \mathrm{~ns}$ & $0.80^{* *}$ & $0.10^{* * *}$ & $189.5^{* *}$ & $1.00 \mathrm{~ns}$ \\
\hline Var x GB & 2 & $1.04 \mathrm{~ns}$ & $3.49^{* * *}$ & $0.003 \mathrm{~ns}$ & $0.008 \mathrm{~ns}$ & $25.7 \mathrm{~ns}$ & $0.99 \mathrm{~ns}$ \\
\hline Var x Salt x GB & 2 & $1.25^{* *}$ & $3.47^{* *}$ & $0.04 \mathrm{~ns}$ & $0.03 \mathrm{~ns}$ & $3.3^{* *}$ & $1.6 \mathrm{~ns}$ \\
\hline Gr Stages x GB & 2 & $2.45 \mathrm{~ns}$ & $2.58^{* *}$ & $1.23^{* *}$ & $1.05 \mathrm{~ns}$ & $122.4^{* * *}$ & $20.6^{* * *}$ \\
\hline $\begin{array}{l}\text { Var x Gr Stages x } \\
\text { GB }\end{array}$ & 2 & $2.40^{* * *}$ & $1.53^{* *}$ & $0.031 \mathrm{~ns}$ & $0.10 \mathrm{~ns}$ & $8.4 \mathrm{~ns}$ & $0.75 \mathrm{~ns}$ \\
\hline $\begin{array}{l}\text { Salt x Gr Stages x } \\
\text { GB }\end{array}$ & 2 & $3.15^{* * *}$ & $1.05 \mathrm{~ns}$ & $0.31 \mathrm{~ns}$ & $0.9 \mathrm{~ns}$ & $13.2 \mathrm{~ns}$ & $0.90 \mathrm{~ns}$ \\
\hline $\begin{array}{l}\text { Var x Salt x Gr } \\
\text { Stages x GB }\end{array}$ & 2 & $3.22^{* * *}$ & $2.4 \mathrm{~ns}$ & $0.21 \mathrm{~ns}$ & $0.2 \mathrm{~ns}$ & $17.4 \mathrm{~ns}$ & $1.54 * *$ \\
\hline \multicolumn{1}{|c|}{ Error } & 72 & 1.04 & 2.07 & 0.25 & 0.088 & 10.5 & 0.105 \\
\hline
\end{tabular}

\section{Photosynthetic pigments}

Analysis of variance of data shown in Table 2 represented that salt stress significantly reduced the photosynthetic pigments in both varieties of wheat. Foliar application of GB significantly enhanced this biochemical attribute of both wheat varieties under normal and salt stress. However, there was not significant increase in chlorophyll b by application of exogenous GB under salt stress. Both varieties showed different response for chlorophyll $\mathrm{a}$ and $\mathrm{b}$ in salt treated plants, whereas both varieties showed same results for carotenoids. Different concentrations of foliar application of GB 0,50 and $100 \mathrm{mM}$ affected these pigments in salt treated and non-treated plants. The effect of exogenous GB was significant in non treated plants, whereas in salt treated plants Chl 'a' and carotenoids were significantly improved. However, application of GB did not significantly affect $\mathrm{Chl}$ a and $\mathrm{Chl} b$ when applied as foliar spray at two growth stages of wheat. Both varieties showed random results in response to $50 \mathrm{mM}$ and $100 \mathrm{mM}$ under normal and saline conditions (Figs. $2 a$ and $b$ ).

Table 2. Mean squares from ANOVA of data for Chl $a, C h l b$ and carotenoids of wheat (Triticum aestivum L.) two varieties when different levels of $\mathrm{GB}$ were used as foliar spray under $\mathrm{Na}_{2} \mathrm{SO}_{4}$ at the vegetative and reproductive stages

\begin{tabular}{|l|c|c|c|c|}
\hline SOV & d.f & Chlorophyll a & Chlorophyll b & Carotenoids \\
\hline Salt & 1 & $2.9^{* *}$ & $0.37^{* * *}$ & $32.5^{* *}$ \\
\hline Var & 1 & $0.48 \mathrm{~ns}$ & $0.009 \mathrm{~ns}$ & $32.1^{* * *}$ \\
\hline Var x Salt & 1 & $1.002^{*}$ & $0.07^{*}$ & $25.6 \mathrm{~ns}$ \\
\hline Gr x Stages & 1 & $1.21^{* * *}$ & $0.05^{* * *}$ & $35.8 \mathrm{~ns}$ \\
\hline Var x Gr Stages & 1 & $0.001 \mathrm{~ns}$ & $0.003 \mathrm{~ns}$ & $47.8^{* * *}$ \\
\hline Salt x Gr Stages & 1 & $0.10 \mathrm{~ns}$ & $0.013 \mathrm{~ns}$ & $35.8^{* *}$ \\
\hline Salt x Var x Gr Stages & 1 & $0.047 \mathrm{~ns}$ & $0.15^{* *}$ & $31.4 \mathrm{~ns}$ \\
\hline GB & 2 & $0.87^{* * *}$ & $0.10^{* * *}$ & $32.5^{*}$ \\
\hline Salt x GB & 2 & $0.20^{* *}$ & $0.010 \mathrm{~ns}$ & $31.4^{* * *}$ \\
\hline Var x GB & 2 & $0.09 \mathrm{~ns}$ & $0.009 \mathrm{~ns}$ & $45.4^{* *}$ \\
\hline Var x Salt x GB & 2 & $0.014 \mathrm{~ns}$ & $0.10 \mathrm{~ns}$ & $25.8^{* *}$ \\
\hline Gr Stages x GB & 2 & $0.15^{*}$ & $0.015^{* *}$ & $35.8 \mathrm{~ns}$ \\
\hline Var x Gr Stages x GB & 2 & $0.09 \mathrm{~ns}$ & $0.008 \mathrm{~ns}$ & $14.5 \mathrm{~ns}$ \\
\hline Salt x Gr Stages x GB & 2 & $0.008 \mathrm{~ns}$ & $0.007 \mathrm{~ns}$ & $36.5^{* * *}$ \\
\hline Var x Salt x Gr Stages x GB & 2 & $0.006 \mathrm{~ns}$ & $0.002 \mathrm{~ns}$ & $23.6 \mathrm{~ns}$ \\
\hline \multicolumn{1}{|c|}{ Error } & 72 & 0.002 & 0.006 & 14.6 \\
\hline
\end{tabular}



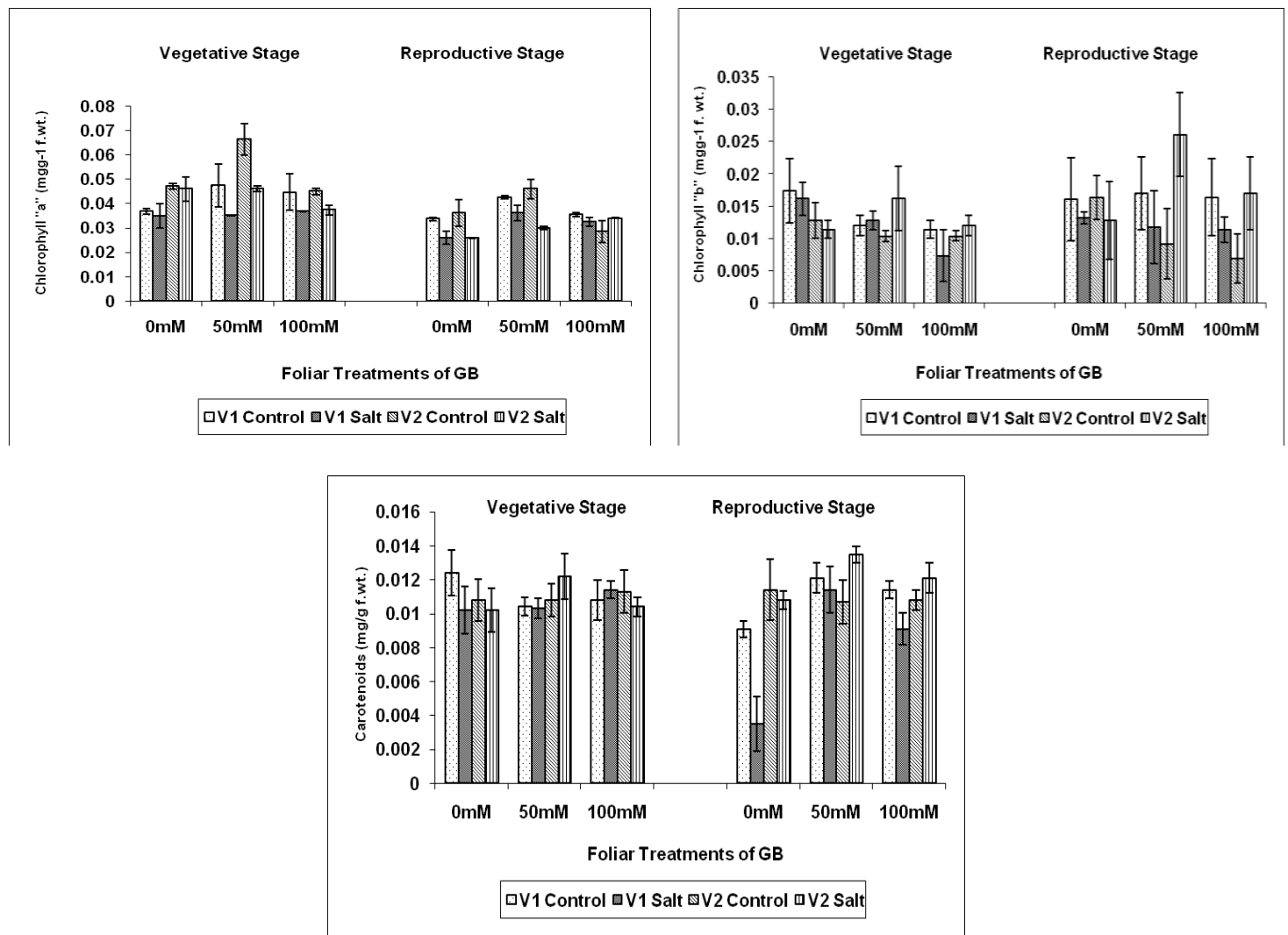

Figure 2. Impact of foliar spray of GB on chlorophyll a (a), chlorophyll b (b), carotenoids (c) of two varieties of wheat (Triticum aestivum $\mathrm{L}$.) under $\mathrm{Na}_{2} \mathrm{SO}_{4}$ stress

\section{Gaseous exchange attributes}

ANOVA of data presented in Table 3 showed that salt stress significantly reduced the gaseous exchange parameters i.e. Net $\mathrm{CO}_{2}$ assimilation rate $(A)$, Transpiration rate $(E)$, Substomatal $\mathrm{CO}_{2}$ concentration $(\mathrm{Ci})$ and Stomatal Conductance to water vapors $(g s)$. Both varieties significantly differ under normal conditions for all these physiological parameters but under adverse conditions varieties did not show different response for $A$ and $E$. Application of foliar GB $(50 \mathrm{mM}, 100 \mathrm{mM})$ was found to be effective in improving the values of $A, E$, and $C i$ and $g s$ in saline as well as non-saline conditions. $100 \mathrm{mM}$ GB was found to be more efficient than $50 \mathrm{mM}$ to combat the adverse effects applied at both vegetative and reproductive stages (Figs. 3a,b,c and d). The interaction Salt x Gr Stages x GB was non significant and significant for $A$ and $E$ and $C i$ and $g s$ respectively.

Table 3. Mean squares from ANOVA of data for gaseous exchange parameters of wheat (Triticum aestivum L.) two varieties when different levels of GB were used as foliar spray under $\mathrm{Na}_{2} \mathrm{SO}_{4}$ at the vegetative and reproductive stages

\begin{tabular}{|c|c|c|c|c|c|}
\hline SOV & d.f & $A$ & $E$ & $C i$ & $g s$ \\
\hline Salt & 1 & $1139.5^{* * *}$ & $12.4^{* * *}$ & $239134.9^{* * *}$ & $2426.9^{* * *}$ \\
\hline Var & 1 & $30.9^{* *}$ & $0.72^{* *}$ & $13785.6^{* * *}$ & $419.3^{* * *}$ \\
\hline Var x Salt & 1 & $0.9 \mathrm{~ns}$ & $0.10 \mathrm{~ns}$ & $7800.1^{* * *}$ & $766.6^{* * *}$ \\
\hline Gr x Stages & 1 & $34.9^{* * *}$ & $0.23 \mathrm{~ns}$ & $15121.3^{* * *}$ & $17.2 \mathrm{~ns}$ \\
\hline Var x Gr Stages & 1 & $1.039 \mathrm{~ns}$ & $0.321^{*}$ & $243.9^{* * *}$ & $49.4 \mathrm{~ns}$ \\
\hline Salt x Gr Stages & 1 & $1.9 \mathrm{~ns}$ & $0.01 \mathrm{~ns}$ & $2544.9^{* * *}$ & $12.1 \mathrm{~ns}$ \\
\hline
\end{tabular}




\begin{tabular}{|c|c|c|c|c|c|}
\hline Salt x Var x Gr Stages & 1 & $0.15 \mathrm{~ns}$ & $0.31^{*}$ & $501.5^{* * *}$ & $40.1 \mathrm{~ns}$ \\
\hline GB & 2 & $55.5^{* *}$ & $0.34^{*}$ & $18722.6^{* * *}$ & $130.9^{* *}$ \\
\hline Salt x GB & 2 & $9.2 \mathrm{~ns}$ & $0.001 \mathrm{~ns}$ & $150.3 \mathrm{~ns}$ & $44.7 \mathrm{~ns}$ \\
\hline Var x GB & 2 & $0.23 \mathrm{~ns}$ & $0.15 \mathrm{~ns}$ & $329.5^{* *}$ & $53.3 \mathrm{~ns}$ \\
\hline Var x Salt x GB & 2 & $0.72 \mathrm{~ns}$ & $0.23 \mathrm{~ns}$ & $2429.8^{* * *}$ & $19.2 \mathrm{~ns}$ \\
\hline Gr Stages x GB & 2 & $12.9^{* * *}$ & $0.12 \mathrm{~ns}$ & $2025.5^{* *}$ & $72.3^{* *}$ \\
\hline Var x Gr Stages x GB & 2 & $0.20 \mathrm{~ns}$ & $0.09 \mathrm{~ns}$ & $795.3^{* * *}$ & $18.2 \mathrm{~ns}$ \\
\hline Salt x Gr Stages x GB & 2 & $1.9 \mathrm{~ns}$ & $0.02 \mathrm{~ns}$ & $269.1^{*}$ & $65.2^{* *}$ \\
\hline Var x Salt x Gr Stages x GB & 2 & $0.099 \mathrm{~ns}$ & $0.03 \mathrm{~ms}$ & $257.9^{*}$ & $61.2^{*}$ \\
\hline Error & 72 & 1.1 & 0.09 & 71.4 & 18.6 \\
\hline
\end{tabular}
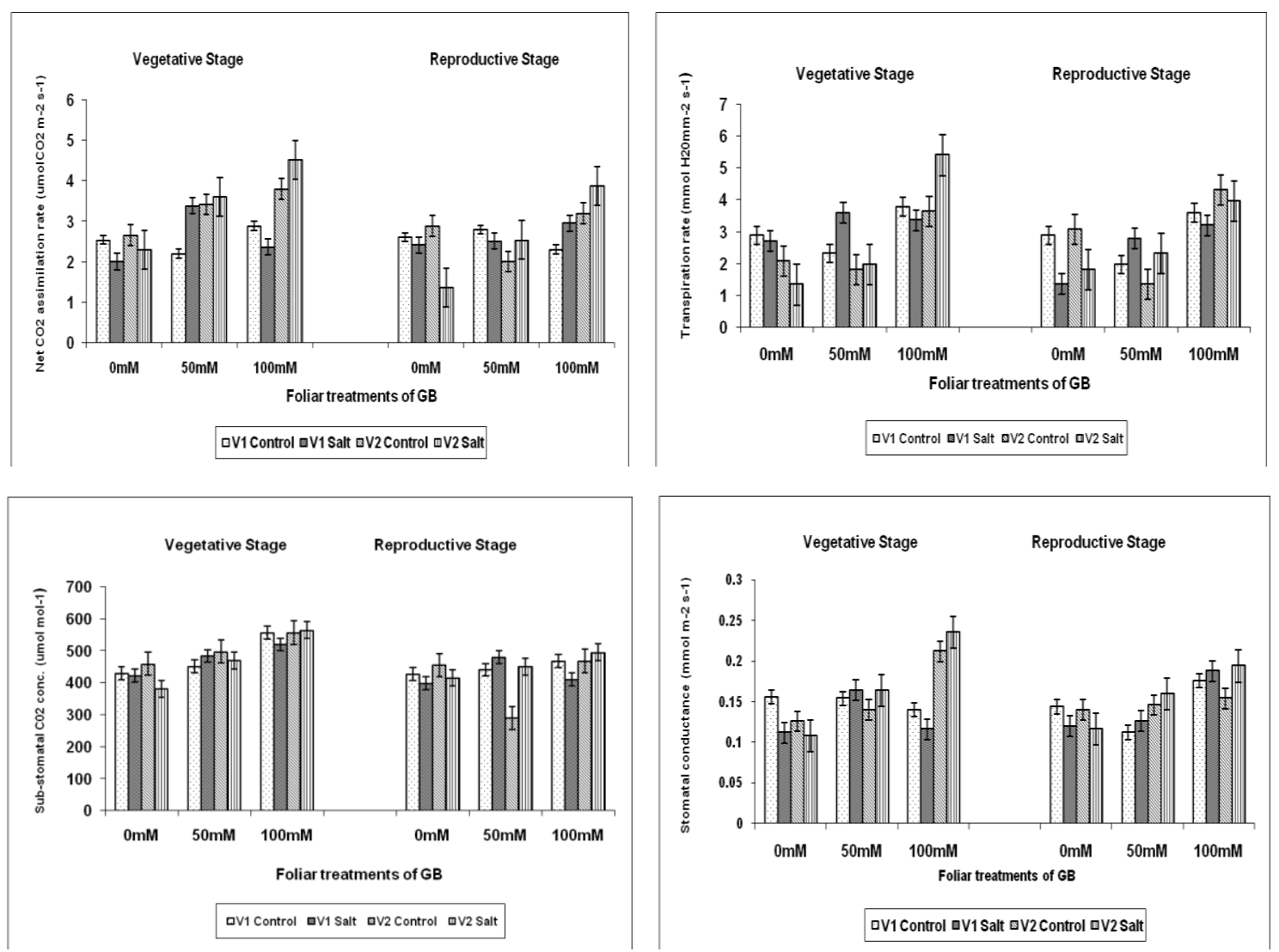

Figure 3. Impact of foliar spray of $\mathrm{GB}$ on net $\mathrm{CO}_{2}$ assimilation rate (a), transpiration rate (b), substomatal $\mathrm{CO}_{2}$ concentration (c), stomatal conductance (d) of two varieties of wheat (Triticum aestivum L.) under $\mathrm{Na}_{2} \mathrm{SO}_{4}$ stress

\section{Catalase and Peroxidase activities}

Salt stress reduced the catalase (CAT) and peroxidase (POD) activities in both wheat varieties (Figs. $4 a$ and $b$ ). However, foliar spray of GB at different growth stages significantly increased CAT and POD activities under normal and adverse conditions. Foliar application of GB $(100 \mathrm{mM})$ was more effective than $50 \mathrm{mM}$. Under saline conditions, a maximum CAT activity (4.21 units/mg protein) was observed in V1 when $100 \mathrm{~m} M$ GB was sprayed at vegetative stage. The salt stressed plants of $\mathrm{V} 1$ had higher CAD activity than those of V2 at $100 \mathrm{~m} M$ GB level especially when sprayed at the vegetative stage. Peroxidase activity of the salt-treated and non-treated plants of both 
wheat varieties was enhanced with exogenous GB (Fig. 4b). Both levels of GB were almost equally effective in affecting the POD activity in salt treated plants. Foliar spray of GB at the vegetative stage was more useful than reproductive stage in improving the POD activity in plants grown under both normal and stress environments.
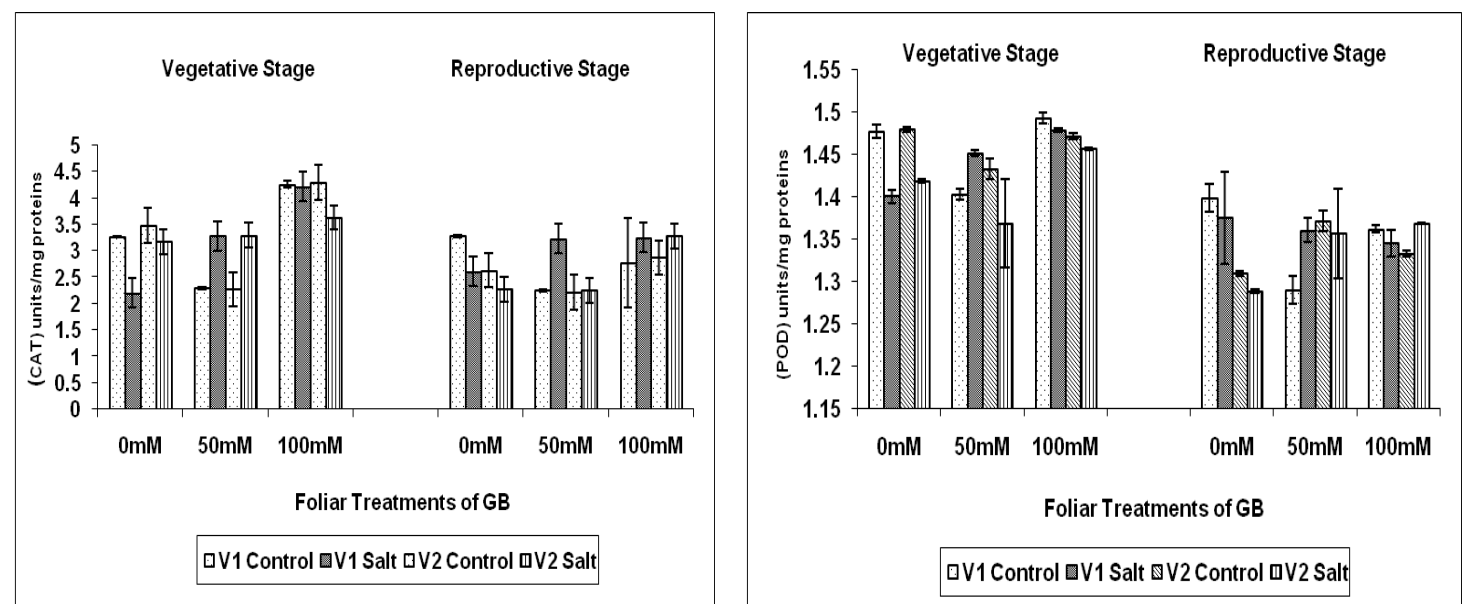

Figure 4. Impact of foliar spray of $G B$ on $C A T(a)$ and $P O D(b)$ activity of two varieties of wheat $\mathrm{GB}$ (Triticum aestivum $\mathrm{L}$.) under $\mathrm{Na}_{2} \mathrm{SO}_{4}$ stress

Table 4. Mean squares from ANOVA of data for CAT and POD activities of wheat (Triticum aestivum $L$.) two varieties when different levels of $G B$ were used as foliar spray under $\mathrm{Na}_{2} \mathrm{SO}_{4}$ at the vegetative and reproductive stages

\begin{tabular}{|l|c|c|c|}
\hline SOV & d.f & CAT Activity & POD Activity \\
\hline Salt & 1 & $115.9 \mathrm{~ns}$ & $1395.3^{* * *}$ \\
\hline Var & 1 & $32.3 \mathrm{~ns}$ & $4932.3^{* * *}$ \\
\hline Var x Salt & 1 & $12072.3^{* * *}$ & $801.2^{* * *}$ \\
\hline Gr x Stages & 1 & $315.9^{* *}$ & $135.9^{* *}$ \\
\hline Var x Gr Stages & 1 & $81.5 \mathrm{~ns}$ & $420.9^{* * *}$ \\
\hline Salt x Gr Stages & 1 & $235.7 \mathrm{~ns}$ & $185.8^{* *}$ \\
\hline Salt x Var x Gr Stages & 1 & $1875.7^{* * *}$ & $29.2 \mathrm{~ns}$ \\
\hline GB & 2 & $397.9^{* *}$ & $1596.5^{* * *}$ \\
\hline Salt x GB & 2 & $335.3^{*}$ & $596.3^{* * *}$ \\
\hline Var x GB & 2 & $834.5^{* *}$ & $1589.2^{* * *}$ \\
\hline Var x Salt x GB & 2 & $3139.5 * * *$ & $600.2^{* * *}$ \\
\hline Gr Stages x GB & 2 & $74.4 \mathrm{~ns}$ & $150.3^{*}$ \\
\hline Var x Gr Stages x GB & 2 & $395.7^{* *}$ & $80.8 \mathrm{~ns}$ \\
\hline Salt x Gr Stages x GB & 2 & $32.2 \mathrm{~ns}$ & $50.3 \mathrm{~ns}$ \\
\hline Var x Salt x Gr Stages x GB & 2 & $895.5 \mathrm{~ns}$ & $325.3^{* *}$ \\
\hline Error & 72 & 69.5 & 30.2 \\
\hline
\end{tabular}

\section{Discussion}

This experiment was carried out to determine the impact of exogenously spray of GB at different growth stages of two wheat varieties under salt stress. In this study, decrease in root and shoot growth, fresh and dry shoot and root weights; chlorophyll concentration and gaseous exchange parameters have been observed in plants subjected to salinity $\left(\mathrm{Na}_{2} \mathrm{SO}_{4}\right)$ stress. The decline in growth and biomass may be due to different reasons. 
Excess of soluble salts in the growth medium disturb the plant water relations, absorption and assimilation of essential nutrients. There are three physiological reasons responsible for the inhibition of growth. These reasons include (a) Turgor pressure reductions in expanding tissues, (b) reductions in photosystem activity and (c) direct effects of toxic accumulated ions on vital metabolic steps in meristematic and expanding cells (Newman, 1997). These changes, disturb the activities of various enzymes and hence the plant metabolism is affected (Munns, 2002; Lacerda et al., 2003). Inhibition of growth is the primary injury that results in the appearance of symptoms. Salt stress activates abscisic acid (ABA) biosynthesis pathway. ABA when transported to the guard cells of the stomata, the stomata become close. The stomatal closure leads to decrease in rate of photosynthesis. Oxidative stress may also occur due to photoinhibition. An immediate effect of osmotic stress caused by salt stress is the inhibition of growth by inhibiting cell expansion either directly or indirectly through ABA (Jouyban, 2012). Salt stress had adverse impact on the rate of photosynthesis, enzyme activity. Salt stress reduces the carbohydrates and growth hormones levels, both of which can reduce the growth (Mazher et al., 2007). Chlorophyll contents reduced due to accumulation of toxic ions and physiological problems noticed during stomata opening and closing under salt stress (Seemann and Critchley, 1985; Aranda and Syvertsen, 1996; Molazem et al., 2010, Nawaz et al., 2010). Rapid maturing of leaves under adverse condition may also be the reason of low chlorophyll contents (Yeo et al., 1991).

Exogenous application of GB improves the growth and development of plants under stressful conditions (Sakamoto and Murata, 2002; Park et al., 2006). It is generally accepted that the increase in cellular osmolality that results from the accumulation of nontoxic, osmotically active solutes such as GB provide turgor pressure necessary for cell expansion (Hare et al., 1998). The development of plants, mainly depends upon the rate of photosynthesis which is adversely affected by salt stress, especially sensitive genotypes of all crops (Kausar et al., 2015). Photosynthesis in two wheat varieties was inhibited due to salt stress; however, foliar application of GB alleviated this adverse effect. Increase in photosynthetic rate was due to high amount of GB under salinity stress. Similar results have also been found in some crops such as tomato (Makela et al., 1998), maize (Yang and Lu, 2005; Nawaz and Ashraf, 2010) and wheat (Rajasekaran et al., 1997; Raza et al., 2006). Foliarly applied GB regulates photosynthesis through stomatal and non-stomatal factors. GB stabilized oxygen-evolving centre and protect PSII (Papageorgiou et al., 1991), and proteins associated with PSII complex under salinity stress (Murata et al., 1992; Sakamoto and Murata, 2002). GB increased the activity of Rubsico in tomato (Makela et al., 1999) and PEP carboxylase in C4 halophytes (Manetas et al., 1986) under salt stress. Rajasekaran et al. (1997) found that GB spray improved the value of $g s$ which resulted in significant increase in net $\mathrm{CO}_{2}$ assimilation rate in wheat.

In our study, gs was significantly reduced in salt treated plants of both wheat varieties than that in non-treated plants (Fig. 3d). However, exogenous application of GB improved the stomatal conductance. The photosynthetic rate $(A)$ and stomatal conductance $(g s)$ are positively correlated. $A$ and $g s$ were also positively correlated with $(C i)$. These results confirm that foliarly applied GB alleviates the toxic effects of salt stress on photosynthetic rate due to stomatal factors. GB may also regulate $g s$ and $E$ through ABA (Makela et al., 1999). Exogenous application of GB had a useful effect on chlorophyll contents (chlorophyll a and b) in salt-treated plants of wheat. Higher leaf 
chlorophyll contents due to foliar spray of GB are one of the additional factors that may have contribution to enhance Net $\mathrm{CO}_{2}$ assimilation rate under saline environment.

Abiotic stresses results in the formation of Reactive oxygen species (ROS) (Hoque et al., 2007) due to electron leakage from photosynthetic and respiratory electron transport chains to molecular oxygen (Hernandez et al., 2001). The ROS can damage lipids, proteins and nucleic acids by causing oxidative stress and disturb normal metabolism (McCord, 2000). These ROS also result in Membrane injury under salt stress (Mittler, 2002). Plants have different mechanisms to scavenge these toxic ROS either by synthesizing different antioxidant compounds or by activating antioxidant enzymes (Mittler, 2002; Ashraf, 2009). Catalase is a potential enzyme which is capable to detoxify two molecules of $\mathrm{H}_{2} \mathrm{O}_{2}$ to water and oxygen and thus is considered as an efficient ROS detoxifier (Hasanuzzaman et al., 2014). There are many reports on the changes in CAT activity or expression and these supported this view about CAT (Hasanuzzaman et al., 2014; Mhamdi et al., 2010). In our study, $\mathrm{Na}_{2} \mathrm{SO}_{4}$ stress caused the reduction in CAT and POD activities in both wheat varieties (Figs. $4 a$ and $b$ ), but foliar spray of GB improved their activities when sprayed at the both growth stages. The effect of GB application on CAT and POD activities was not significant when GB applied at different growth stages (Table 4). Ma et al. (2006) found that foliar application of GB increased SOD and APX activities of wheat plants under water-stress. It is suggested exogenous GB can increased the salinity tolerance by enhancement of the components of antioxidant defense and glyoxalase systems (Heuer, 2003).

It can be concluded that foliar spray of GB was useful in alleviating the negative effects of salt stress on growth, photosynthesis and antioxidants of both wheat varieties. Positive results of exogenous GB were due to its improvement in photosynthetic capacity through stomatal factors, accumulation of GB, its protective effect on stability of cell membrane and photosynthetic machinery. GB is an important osmoprotectant and play important role in osmotic adjustment. GB also increased the antioxidant activities to prevent damage from oxidative stress.

\section{REFERENCES}

[1] Agboma, P.C., Sinclair, T.R., Jokinen, K., Peltonen-Sainio, P., Pehu., E. (1997): An evaluation of the effect of exogenous glycinebetaine on the growth and yield of soybean: timing of application, watering regimes and cultivars. - Field Crop Research 54: 51-64.

[2] Aranda, R.R., Syvertsen, J.P. (1996): The influence of foliar applied urea nitrogen and salina solutions on net gas exchange of citrus leaves. - Journal of the American Society for Horticultural Science 121: 501-506.

[3] Arnon, D.T. (1949): Copper enzyme in isolated chloroplasts, polyphenaloxidase in Beta vulgaris. - Plant Physiology 24: 1-15.

[4] Asada, K. (1999): The water-water cycle in chloroplasts: Scavenging of active oxygen and dissipation of excess photons. - Annual Review of Plant Physiology and Plant Molecular Biology 50:601- 639.

[5] Ashraf, M. (2009): Biotechnological approach of improving plant salt tolerance using antioxidants as markers. - Biotechnology Advances 27(1):84-93.

[6] Ashraf, M., Foolad, M.R. (2007): Roles of glycine betaine and proline in improving plant abiotic stress resistance. - Environmental and Experimental Botany 59: 206-216.

[7] Ashraf, M., Harris, P.J.C. (2004): Potential biochemical indicators of salinity tolerance in plants. - Plant Science 166: 3-16. 
[8] Ashraf, M., Sultana, R. (2000): Combined effect of $\mathrm{NaCl}$ salinity and N-form on mineral composition of sunflower plants. - Biologia Plantarum 43: 615-619.

[9] Azevedo-Neto, A.D., Prisco, J.T., Enéas-Filho, J., Abreu, C.E.B., Gomes-Filho, E. (2006): Effects of salt stress on antioxidative enzymes and lipid peroxidation in leaves and roots of salt-tolerant and salt-sensitive maize genotypes. - Environmental and Experimental Botany 56:87-94.

[10] Bray, E., Bailey-Serres, J., Weretilinyk, E. (2002): Responses to Abiotic Stresses. - In: Buchanan, B., Gruissem, W., Jones, R. (Eds.) Biochemistry and Molecular Biology of Plants ASPB, John Wiley andSons, pp. 1158-1202.

[11] Chance, M., Maehly, A. C. (1955): Assay of catalases and peroxidases. - Methods in Enzymology 2: 764-817.

[12] Cusido, R.M., Palazon, J., Altabell, T., Morates, C. (1987): Effect of salinity on soluble protein, free amino acids and nicotinic content in Nicotiana rustica L. - Plant Physiology 102:55-60.

[13] Debez, A., Saadaoui, D., Ramani, B., Ouerghi, Z., Koyro, H.W., Huchzermeyer, B., Abdelly, C . (2006): Leaf $\mathrm{H}^{+}$- ATPase activity and photosynthetic capacity of Cakile maritime under increasing salinity. - Environmental and Experimental Botany 57: 285-29.

[14] Gorham, J., Wyn Jones, R.G., McDonell, E. (1985): Some mechanisms of salt tolerance in crop plants. - Plant Soil 89:15-40.

[15] Greenway, H., Munns, S.R. (1980): Mechanism of salt tolerance in non- halophytes. Annual Review of Plant Physiology 31:149-190.

[16] Hare, P.D., Cress, W.A,, Staden, J.V. (1998): Dissecting the roles of osmolyte accumulation during stress. - Plant Cell and Environment 21: 535-553.

[17] Harinasut, P., Tsutsui, K., Takabe, T., Nomura, M., Kishitani, S. (1996): Exogenous glycinebetaine accumulation and increased salt tolerance in rice seedlings. - Bioscience, Biotechnology and Biochemistry 60: 366-368.

[18] Hasanuzzaman, M., Alam, M. M., Rahman, A., Hasanuzzaman, Md., Nahar, K., Fujita, M. (2014): Exogenous Proline and Glycine Betaine Mediated Upregulation of Antioxidant Defense and Glyoxalase Systems Provides Better Protection against SaltInduced Oxidative Stress in Two Rice (Oryza sativa L.) Varieties. - BioMedical Research Intern ID 757219, 1-17.

[19] Hernandez, J.A., Ferrer, M.A., Jimenez, A., Ros Barcelo, A., Sevilla, F. (2001): Antioxidant systems and $\mathrm{O} 2-/ \mathrm{H} 2 \mathrm{O} 2$ production in the apoplast of Pisum sativum L. leaves its relation with $\mathrm{NaCl}$-induced necrotic lesions in minor veins. - Plant Physiology 127: 817-831.

[20] Heuer, B. (2003): Influence of exogenous application of proline and glycine betaine on growth of salt-stressed tomato plants. - Plant Science 165:696-699.

[21] Hoque, M.A., Okuma, E., Banu, M.N.A., Nakamura, Y., Shimoishi, Y., Murata, Y, (2007): Exogenous proline mitigates the detrimental effects of salt stress more than exogenous betaine by increasing antioxidant enzyme activities. - Journal of Plant Physiology 164(5):553-561.

[22] Jouyban, Z. (2012): The Effects of Salt stress on plant growth. - Journal of Engineering and Applied Sciences 2-1/7-10.

[23] Kausar, A., Khurshid, A., Ashraf, M.Y., Ghafoor, R., Gull, M. (2015): Photosynthesis, transpiration, stomatal conductance potential and water uptake in selected rice cultivars (Oryza sativa.) under various saline conditions. - Sylwan159(3): 258-265.

[24] Koyro, H.W. (2006): Effect of salinity on growth, photosynthesis, water realtions and solute composition of the potential cash crop halophyte (Plantago coronopus L.). Environmental and Experimental Botany 56: 136-146.

[25] Lacerda, C.F., Cambraia, J., Cano, M.A.O., Ruiz, H.A., Prisco, J.T. (2003): Solute accumulation and distribution during shoot and leaf development in two sorghum genotypes under salt stress. - Environmental and Experimental Botany 49: 107-120. 
[26] Ma, Q.Q., Wang, W., Li, Y.H., Li, D.Q., Zou, Q. (2006): Alleviation of photoinhibition in drought-stressed wheat (Triticum aestivum L.) by foliar-applied glycinebetaine. - Journal of Plant Physiology 163: 165-175.

[27] Makela, P., Jokinen, K., Kontturi, M., Peltonen-Sainio, P., Pehu, E., Somersalo, S. (1998): Foliar application of glycinebetaine - a novel product from sugar beet - as an approach to increase tomato yield. - Industrial Crops and Products 7: 139-148.

[28] Mäkela, P., Kontturi, M., Pehu, E., Somersalo, S. (1999): Photosynthetic response of drought and salt stressed tomato and turnip rape plants to foliarly applied glycinebetaine. - Physiologia Plantarum 105: 45-50.

[29] Manetas, Y., Petropoulou, Y., Karabourniotis, G. (1986): Compatible solutes and their effects on phosphoenolpyruvate carboxylase of C4-halophytes. - Plant Cell and Environment 9: 145-151.

[30] Mazher, A.M.A., El-Quesni, E.M.F., Farahat, M.M. (2007): Responses of ornamental and woody trees to salinity. - World Journal of Agricultural Sciences 3 (3): 386-395.

[31] McCord, J.M. (2000): The evolution of free radicals and oxidative stress. - American Journal of Medicine 108: 652-659.

[32] Meiri, A., Kamburoff, J., Poijakoff-Mayber, A. (1971): Response of bean plants to sodium chloride and sodium sulphate salinization. - Annals of Botany 35:837-847.

[33] Mhamdi, A., Queval, G., Chaouch, S., Vanderauwera, S., van Breusegem. F., Noctor, G, (2010): Catalase function in plants: a focus on Arabidopsis mutants as stress-mimic models. - Journal of Experimental Botany 61(15):4197-4220.

[34] Mittler, R. (2002): Oxidative stress, antioxidants and stress tolerance. - Trends in Plant Science 7: 405-410.

[35] Molazem, D., Qurbanov, E.M., Dunyamaliyev, S.A. (2010): Role of proline, Na and chlorophyll content in salt tolerance of corn (Zea mays) L. - American-Eurasian Journal Agricultural and Environmental Sciences 9: 319-324.

[36] Munns, R. (2002): Comparative physiology of salt and water stress. - Plant Cell and Environment 25: 239-250.

[37] Nawaz, K., Ashraf, M., Akram, N.A., Al-Qurainy, F. (2010): Modulation of growth parameters, proline contents and mineral nutrients in maize (Zea mays $\mathrm{L}$ ) by exogenously applied glycinebetaine at different growth stages under salt stress. - Journal of Applied Botany and Food Quality 83, 204-211.

[38] Nawaz, K., Ashraf, M. (2010): Exogenous Application of Glycinebetaine Modulates Activities of Antioxidants in Maize Plants Subjected to Salt Stress. - Journal of Agronomy and Crop Science 196:28-37.

[39] Newman, P. (1997): Salinity resistance and plant growth revisited. - Plant Cell and Environment 20: 1193-1198.

[40] Papageorgiou, G.C., Fujimuram, Y., Murata, N. (1991): Protection of the oxygenevolving Photosystem II complex by glycinebetaine. - Biochimica et Biophysica Acta 1057: 361-366.

[41] Park, E.J., Jeknic, Z., Chen, T.H. (2006): Exogenous application of glycinebetaine increases chilling tolerance in tomato plants. -Plant and Cell Physiology 47:706-14.

[42] Rajasekaran, L.R., Kriedemann, P.E., Aspinall, D., Paleg, L.G. (1997): Physiological significance of proline and glycine betaine: Maintaining photosynthesis during $\mathrm{NaCl}$ stress in wheat. -Photosynthetica 34: 357-366.

[43] Ramoliya, P., Patel, H., Pandy, A.N. (2004): Effect of salinization of soil on growth and macro- and micro-nutrient in seedlings of Salvadora persica (Salvadoraceae). -Forest Ecology and Mangement 202(1-3):181-193.

[44] Raza, S.H., Athar, H.R., Ashraf, M. (2006): Influence of exogenously applied glycinebetaine on the photosynthetic capacity of two differently adapted wheat cultivars under salt stress. - Pakistan Journal of Botany 38: 341-251. 
[45] Raza, S.H., Athar, H.R., Ashraf, M., Hameed, A. (2007): Glycinebetaine-induced modulation of antioxidant enzymes activities and ion accumulation in two wheat cultivars differing in salt tolerance. -Environmental and Experimental Botany 3:368-376.

[46] Rout, N.P., Shaw, B.P. (2001): Salt tolerance in aquatic macrophytes: possible involvement of the anti oxidative enzymes. - Plant Science 160:415-423.

[47] Sakamoto, A., Murata, N. (2002): The role of glycine betaine in the protection of plants from stress: cues from transgenic plants. -Plant Cell and Environment 25:163-170.

[48] Seemann, J.R., Critchley, C. (1985): Effects of salt stress on the growth, ion content, stomatal behavior and photosynthetic capacity of a salt sensitive species, Phaseolus vulagris L. - Plant Physiology 82: 555-560.

[49] Stepien, P., Klobus, G. (2006): Water relations and photosynthesis in Cucumis sativus L. leaves under salt stress. -Biologia Plantarum 50(40): 610- 616.

[50] Yang, X., Lu, C. (2005): Photosynthesis is improved by exogenous glycinebetaine in salt stressed maize plants. -Physiologia Plantarum 124: 343-352.

[51] Yeo, A.R., Lee, K.S., Izard, P., Boursier, P.J, Flowers, T.J. (1991): Short and long term effects of salinity on leaf growth in Rice (Oryza sativa L.). - Journal of Experimental Botany 42: 881-889.

[52] Zafar, S., Ashraf, M.Y., Niaz, M., Kausar, A., Hussain, J. (2015): Evaluation of wheat genotypes for salinity tolerance using physiological indices as screening tool. -Pakistan Journal of Botany 47: 397-405. 